\title{
Sandcastles: a dystopia
}

\author{
Caught up in a storm.
}

\section{Kathryn Cramer}

You had big summer plans to revive the mathematics career that might have been but wasn't. But there were your children, their eyes trained upon you. Here we are. Entertain us. You shoot endless camcorder footage of your son catching frogs; of your daughter taking off her shoes while you say in the background: "Don't you dare take off those shoes." At the end of the summer, you vacation with your mother-in-law, age 93. She watches TV while you, your husband and kids go to the beach.

You return to the cottage wanting to talk about children and their sandcastles and the rising tide; instead your mother-in-law wants to talk about the impending disaster. Unfortunately, your mother-in-law knows her hurricanes. And so you return home. You read the weather on the web in disbelief. Surely, this is like the comet Kohoutek: the real event will be the advance coverage? Nothing can live up to that; and of course, it doesn't. You dream that your greatgrandmother's bones are floating out to sea. You aren't relieved, as you were in denial in the first place, but you begin to comprehend; and so you see it when it begins to happen.

You have watched children with their sandcastles and you can't get that image out of our mind. Water gradually overwhelming the defences, the castles collapse, surrender to the ocean. A levee breaks. You strive for understanding, find what you think are before-and-after pictures on disparate websites. You bring them together and tell your friends. You were wrong initially, but your attempts attract a swarm of helpful techies. Cameramen in 'copters snap photos that appear on the web, seemingly of 'the' break. Satellite images are at your fingertips. You compare, contrast, argue. You and your newfound friends, most of whom you've never met and whom you know only by handle, realize with growing horror that the situation is worse, much worse, than anyone has yet described. Not one break, but three or four. Thousands of people are going to die, but you don't yet dare say what you understand, for how could a housewife with a fancy computer set-up understand it before those who should be saving those people?

You begin to get specific addresses in the mail. No one is helping, maybe you can? hello $i$ was trying to find the condition of my home my address was... my two dogs were left there. You answer that. And another and another and another. You can't run the software your newfound techie friends are using, but they send you JPEGs, amazing JPEGs. You feel like you are watching progress in Civil War medicine in fast-forward; amazing innovations in digital cartography are happening overnight, there for you when you wake up in the morning. And what you see then is beautiful and terrifying. You can't play too. All you can do is publish the images and make suggestions. And answer and answer and answer. Someone else asks you how you can help her relatives escape.

You try your best. A reporter, impressed with the pictures, gets in touch, and you are interviewed.

When you arrive at your friends' house for the weekend, in a place so remote that cell phones don't work, you check your e-mail and discover many more requests for help, along with four requests for interviews. By the end of the weekend, you are world famous. The world is looking for good news, and for a few days, you are it a bright spot in the bleakness. Meanwhile, the scenario you understood unfolds and unfolds and unfolds. You really did understand things long before those who are supposed to be keeping watch. It seems impossible, but you did. Many more people are dying and you know it, and you are doing what you can, but it is not enough, cannot be enough, because you are a smart housewife with a computer and all you can do is write.

And you write and write, because people want to know if their houses are under water, if their dogs or relatives or friends are dead. And they know you can help, because it said so in The New York Times. You have left politics out of it, because you want your help to be available to anyone, no matter what their beliefs. But at a certain point that is no longer possible. What you begin to understand is that when you wrote that the dogs probably didn't drown because there was only 18 inches of water max. at that address, that you were terribly naive. The dogs will be shot; the house razed. But you don't say so, because having exchangede-mails with so many, you think you know how they feel.

And the tide begins to turn: The Collective You is winning. The press won't be silenced after all; the remaining residents can stay; the tabula rasa scenario begins to recede. And you write and write. You have learned to respond, learned a kind of one-on-one compassion and respect that might otherwise have passed you by. But you cannot get back to your own world: you are living in the dystopia in which all hell breaks loose. And now you know. And you watch your children start the school year and you know where they live. Kathryn Cramer is widely credited for having popularized the use of Google Ear th and Google Maps for examining the damage inflicted by Hurricane Katrina. 